\title{
Improve Language and Cognitive Ability Through SAVI Learning Model with Lego Media for Preschool Child in Group A
}

\author{
Dwi Murni Tungga Dewi, Siti Masitoh, \& Bachtiar Syaiful Bachri \\ Pendidikan Dasar Konsentrasi PAUD \\ Universitas Negeri Surabaya \\ Surabaya, Indonesia \\ dwimurni@mhs.unesa.ac.id
}

\begin{abstract}
The purpose of this research was to know the influence of the learning model SAVI with Lego media on language and cognitive development for preschool children (4-5 years old). This quantitative research approach used an experimental research method with research of Nonequivalent Control Group Design. The results of research based on different language and cognitive developmental test results for pretest and posttest that there are differences in language development and cognitive development between control and experiment groups. It could be seen through the result value of posttest language development in experiment group is greater than the mean of control group language development that is 22.89>13.2. While the mean value of posttest cognitive development in the experimental group is greater than the mean value of control group cognitive development that is $54.02>33.03$. These results indicate that SAVI learning model with Lego media effect on language and cognitive for the preschool child (4-5 years old).
\end{abstract}

\section{Keywords-SAVI; Lego; Media; Cognitive; Language}

\section{INTRODUCTION}

Kindergarten is one form of the implementation of an education channel early childhood education formal for children age 4 to 6 years. The aspect of the development of the baby that was developed in the kindergarten school is the aspect of planting moral values and religion, physical, cognitive, language, the arts and social-emotional. The development of the baby taken place in a sustainable and as distinct from each other which are affected by the internal factor and externally.

Performances level of childhood development in the language side for the group aged 4-5 years old are they are able to express their opinion and answer the question properly [1]

The ability to express language to preschool children is a part of language growth range. It is one of the important aspects that influence the next level. Speech is a form of articulation or language using words that are used to deliver [2]Language is critical for cognitive development. Language provides a means for expressing ideas and asking a question and it provides the categories and concept for thinking [3]Language is a tool to express an idea and ask, and language also delivers concepts and categories to think. Speech is key to these functions because it helps the children direct their own actions; for example, what to do with their hands, bodies, and voices, which in turn is part of developing self-regulation [16].

The ability to express language also influences children thinking ability because language is a tool to deliver their thought. The fast of language growth and the symbolic game were the example of symbolic thought in the early preschool level and children started to use their rough plan to draw people, houses, cars, clouds, and many other aspects in the world [4]This symbolic thought will help children to think symbolic and logic especially in classifying things based on the shape and color. Classification also called sorting or grouping or categorizing, extend matching two objects that are similar to matching groups of the object that share common characteristic or attributes [5]

To accommodate the child's development in language and cognition, should draw an interesting learning model and can invite children to participate actively in learning. The learning model can be a learning activity that must be done so that teachers and students learning objectives can be achieved effectively and efficiently [6]

Based on researcher's observation at Kindergarten in Surabaya got data of language and cognitive ability of the child is still low. It shows many children who have not classified objects according to the form and of a color. This observation is conducted at the process of the introduction of color, teachers are more likely to give the names of color and a show of colors with the methods including talk when the teacher explained related to the introduction of form. This has resulted in his studies of cognitive development the children do not train or developing the world, the only kid received information and lack of the opportunity to a child to expressed an opinion or just plain answers questions and conducting experiments. It is also because teachers always riveted on children activity sheet that is less than develop the aspect of the development of the baby especially cognitive and the language. The condition of the phenomenon that is in pre-school, different with the opinions of The approach in conducting early childhood education with models, methods, and media of interest to be easily followed by children and can motivate children to think [6]

SAVI learning model is very suited to be applied in learning activities for children's language and cognitive development 
because of it, they will learn through their Somatic, Visual Auditory, and Intellectual. Through Somatic, they will learn to move. Through Auditory, they will learn to express an opinion and understand the teacher's command, then through Visual, they will learn to observe the picture shown by a teacher. The last, through Intellectual, children will learn to think and solve the problem. Learning SAVI can train them to interact with their friends, informants, environment in order to obtain various information [19]. This learning will be more interesting if teachers use media such as Lego. Media aims to provide variety and power Pull the child towards learning in the form of props or other objects that can support the delivery of content [5]. Lego can stimulate children's cognitive ability because they have to think about how to build a strong foundation to be a construction, and what shape will they make Lego be.

Lego media also can develop children's language ability because, in the process, they will be stimulated to take apart with their friends and express their opinion to other people. The benefits of Lego for children are; they can learn to create a mission, to understand about a foundation, to understand helping tools, to communicate and share idea [7]Develop lego/beam provides opportunities for children to make ideas, thinking and imagine so that it can produce the form or works [4]. Guided play activities also may help to better understand the nature of gender differences in block building. Gender differences have been found in the complexity of children's structures during free play with blocks

[8]Using Lego media purposes to maximize SAVI characteristics in learning, as follows: Somatic (involving body and brain to arrange Lego), Auditory (inviting children to speak and cooperate in arranging Lego, solving problem and finding information), Visual (observing and describing example from the real world), and Intellectual (creating and demonstrate the result).

Based on the above descriptions the authors are interested in researching cognitive and language ability through SAVI learning model with lego. It is expected that the results of the research will be able to show that SAVI learning model with lego is influenced by self-confidence and learning style can improve cognitive and language ability.

\section{METHOD}

This research is experimental research using a quantitative approach to find the influence of one treatment to another in the certain condition. A design used in this research was QuasiExperimental type Nonequivalent Control Group Design that is by dividing a group to be two parts; control group and experimental group. The experimental research aims to investigate causality (cause and effect relationship), by way of one or more groups expose experimental and one or more conditions of the experiment [9]

A sample is a subgroup of the target population that the researcher plans to study for generalizing about the target population [1]. A sample of this research contained four schools in Tegal Sari Subdistrict. Those are Darul Ulum Kindergarten, Dwi Matra Kindergarten, Aisyiyah Bustanul Athfal 38 Kindergarten, and Aisyiyah Bustanul Athfal 28 Kindergarten. Two of the schools were the control group and the rest were the experimental group.

Data collection techniques are ways to be taken and tools used by researchers in collecting data [10]The technique of collecting data used in this research was the observation technique. Observation the technique was done by observing children through observation direction. Item Validity Test was being tested by consulting every question to the experts. The researchers asked experts' opinion about the instrument grills so that the validity was examined. After testing by experts was empirical validity test that was arranged based on the proven empirical facts than being counted using product moment correlation coefficient from Karl Pearson helped by software SPSS 22 whereas reliability test was based on Alpha Cronbach.

After doing validity and reliability test and every item is valid, then researchers did the analysis test. This test is done to determine whether the hypothesis is accepted or rejected. To test the hypothesis, researchers used ANOVA (Analysis of Varian) and MANOVA (Multivariate Analysis of Variance).

\section{RESULT AND DISCUSSION}

It is the result of children's language and cognitive progress for validity and reliability. Validity comes from the word that means the extent to which the precision and accuracy of a measuring instrument can perform the function of its size [6]. Here is validity result for every item of language and cognitive progress:

TABLE II. VALIDATION RESULT OF LANGUAGE DEVELOPMENT

\begin{tabular}{lrccc}
\hline & $\begin{array}{c}\text { Scale } \\
\text { Mean if } \\
\text { Item } \\
\text { Deleted }\end{array}$ & $\begin{array}{c}\text { Scale } \\
\text { Variance } \\
\text { if Item } \\
\text { Deleted }\end{array}$ & $\begin{array}{c}\text { Corrected } \\
\text { Item-Total } \\
\text { Correlation }\end{array}$ & $\begin{array}{c}\text { Cronbach's } \\
\text { Alpha if } \\
\text { Item } \\
\text { Deleted }\end{array}$ \\
\cline { 2 - 5 } Item_1 & 25.23 & 9.287 & .351 & .754 \\
Item_2 & 25.21 & 9.641 & .314 & .757 \\
Item_3 & 25.36 & 9.289 & .334 & .756 \\
Item_4 & 25.54 & 9.308 & .320 & .758 \\
Item_5 & 25.31 & 9.429 & .405 & .750 \\
Item_6 & 24.82 & 8.888 & .416 & .748 \\
Item_7 & 25.21 & 9.483 & .311 & .758 \\
Item_8 & 25.49 & 9.256 & .433 & .747 \\
Item_9 & 25.28 & 9.576 & .383 & .752 \\
Item_10 & 25.33 & 9.439 & .365 & .753 \\
Item_11 & 25.41 & 8.985 & .457 & .743 \\
Item_12 & 25.41 & 9.354 & .325 & .757 \\
Item_13 & 25.44 & 8.673 & .548 & .733 \\
Item_14 & 25.31 & 9.219 & .350 & .755 \\
\hline
\end{tabular}

TABLE II. VALIDATION RESULT OF COGNITIVE DEVELOPMENT

\begin{tabular}{lrccc}
\hline & $\begin{array}{c}\text { Scale } \\
\text { Mean if } \\
\text { Item } \\
\text { Deleted }\end{array}$ & $\begin{array}{c}\text { Scale } \\
\text { Variance } \\
\text { if Item } \\
\text { Deleted }\end{array}$ & $\begin{array}{c}\text { Corrected } \\
\text { Item-Total } \\
\text { Correlation }\end{array}$ & $\begin{array}{c}\text { Cronbach's } \\
\text { Alpha if Item } \\
\text { Deleted }\end{array}$ \\
\cline { 2 - 5 } Item_1 & 9.79 & 2.799 & .373 & .582 \\
Item_2 & 9.85 & 2.555 & .354 & .590 \\
Item_3 & 9.69 & 2.798 & .366 & .584 \\
Item_4 & 9.82 & 2.783 & .354 & .587 \\
Item_5 & 9.74 & 2.617 & .355 & .588 \\
Item_6 & 9.69 & 2.692 & .367 & .582 \\
\hline
\end{tabular}

Table can be detected through a significance level of 0.05 and $\mathrm{N}=39$, then obtained table of 0.308 . the validity of the test results of two variables on each item is greater than table $1(0.308)$ thus concluded that the validity of the test item of the variables of 
cognitive development in declared invalid.After validation testing is testing reliability using product moment correlation. Here is reliability result of language and cognitive development:

An instrument having a level the operation of reliability if the instrument measuring the aspects that measured several times is the same to them or relative same [11]If the value of alpha Cronbach $(\alpha)$ greater than 0.60 so of data is considered to be quite good and it is reliable for use as an input in the testing of hypothesis research.

\section{TABLE III. RELIABILITY RESULT OF LANGUAGE AND COGNITIVE}

\begin{tabular}{|c|c|c|c|c|}
\hline \multicolumn{2}{|c|}{ Language Development } & & \multicolumn{2}{|c|}{ Cognitive Development } \\
\hline Cronbach's & & & Cronbach's & \\
\hline Alpha & $\mathrm{N}$ of Items & & Alpha & $\mathrm{N}$ of Items \\
\hline .629 & & 6 & .765 & 14 \\
\hline
\end{tabular}

The results of this reliability for measuring the degree of inveteracy. Value of alpha Cronbach $(\alpha)$ from table 4.3 to his studies of cognitive development is 0,765 . To exceed or more than the value of the debt value of alpha Cronbach $(\alpha)$ namely 0.60 so it can be concluded that instruments of cognitive development it is said it is reliable.

Based on the pretest and posttest result about children's language and cognitive development, it can be stated that there is increasing value in the experimental group. Here is the posttest result of experimental and control group :

TABLE IV. POSTTEST RESULT COGNITIVE DEVELOPMENT

\begin{tabular}{lcc}
\hline \multicolumn{1}{c}{ Value } & Experimental Group & Control Group \\
\hline Average & 54.02 & 33.03 \\
Maximum & 56 & 37 \\
Minimum & 52 & 31 \\
\hline
\end{tabular}

TABLE V. POSTTEST RESULT LANGUAGE DEVELOPMENT

\begin{tabular}{lcc}
\hline \multicolumn{1}{c}{ Value } & Experimental Group & Control Group \\
\hline Average & 22.89 & 13.25 \\
Maximum & 24 & 15 \\
Minimum & 21 & 12 \\
\hline
\end{tabular}

Table IV and Table V showed The average yield control group related cognitive ability is 33.03 . This outcome smaller than a group experiment in that it has value 54.02. This means that the average yield group experimentation with greater large of a group of control. The average yield group experiment the language is that of 22.89 related the ability and the average yield control group the 13.25 means that the value the average group experimentation with greater large of a group of control. It means that the SAVI learning model influences children's language and cognitive development.

Statistic test parametric test statistic is devoted to analyzing data statistic that this variable numerical good is variable with scales interval and ratio [12]Based on the results of homogeneity, linieritas test and got that this data is linear and homogeneous and is statistic parametric. In calculating hypothesis using ANOVA and MANOVA test. Here is $\mathrm{F}$ result for three hypotheses in this research:

\begin{tabular}{lcc}
\hline & $\boldsymbol{F}$ & Category \\
\hline Hypothesis 1 & 3.860 & Ha is accepted \\
\hline Hypothesis 2 & 6.465 & Ha is accepted \\
\hline
\end{tabular}

Based on Table IV, it is known that value of $\mathrm{F}$ count 3.860 in hypothesis 1 and value of significance as much as 0.000 3.07 table and reason while the value of 5 percent or 0.05 percentage point. Fhitung greater than ftabel so that ho reject some and ha received. This item can be concluded SAVI learning model kind of classroom significantly had an influence on the development of a language on child group A in kindergarten.

From Table IV, it is shown that test result was obtained on to test the hypothesis of One-Way ANOVA was broken as much as 6.465 fhitung value and that the value of significance as much as $0.0123 .07 \mathrm{ftabel}$ and reason while the value of 5 percent or 0.05 percentage point. Fhitung greater than ftabel so that ho reject some and ha received. This item can be concluded SAVI learning model kind of classroom significantly of its effect on a group of cognitive development in children in kindergarten.

\section{CONCLUSION}

Based on the results of hypothesis testing and discussion of research, can put forward the conclusion that : (1) the SAVI learning model with Lego media influences language development. It is based on the result of $\mathrm{F}$ count for language development has significance value 0.000 means $<$ sig 0.05 . (2) SAVI learning model with Lego media influences cognitive development. It is based on the result of $\mathrm{F}$ count for cognitive development has significance value 0.012 means $<$ sig 0.05 . 


\section{REFERENCES}

[1] P. N. R. Indonesia, "Undang-Undang Republik Indonesia Nomor 43 Tahun 2007 Tentang Perpustakaan," 2007.

[2] J. W. Creswell, Educational research: Planning, conducting, and evaluating quantitative. Prentice Hall Upper Saddle River, NJ, 2002.

[3] A. Susanto, Perkembangan anak usia dini: Pengantar dari berbagai aspeknya. Kencana, 2011.

[4] J. W. Santrock and J. W. Santrock, "Psikologi Pendidikan edisi kedua." Kencana Prenada Media Group, 2007.

[5] J. J. Beaty, "Observasi perkembangan anak usia dini," Jakarta: Kencana, 2013.

[6] J. Warsihna, "Modul Pelatihan Pengembangan Dan Pemanfaatan Konten Jardiknas Pembuatan Media Video," Dep. Pendidik. Nas. Pus. Teknol. Inf. dan Komun. Pendidik., 2009.

[7] J. W. Sentrock, "Perkembangan Anak Jilid 2," Jakarta: Erlangga, 2007.

[8] G. S. Morrison, "Pendidikan anak usia dini saat ini." Yogyakarta: Pustaka Pelajar, 2016.

[9] S. A. Denham, H. H. Bassett, and K. Zinsser, "Early childhood teachers as socializers of young children's emotional competence," Early Child. Educ. J., vol. 40, no. 3, pp. 137-143, 2012.

[10] D. Darmawan, "Metode penelitian kuantitatif." Bandung: PT Remaja Rosdakarya, 2013.

[11] Sugiyono, Metode penelitian pendidikan:(pendekatan kuantitatif, kualitatif dan $R \& D)$. Alfabeta, 2008.

[12] G. E. Tompkins, Language arts: Content and teaching strategies. ERIC, 1998. 
